\title{
Achieving the Sustainable Development Goals (SDGs) through decentralisation and the role of local governments: a systematic review
}

\section{Commonwealth Journal of Local Governance}

Issue 22: 2019

http://epress.lib.uts.edu.au/ojs/index.php/cjlg

\author{
Joydeep Guha \\ Ministry of Communications \\ Government of India \\ Email: joydeepguha1970@ gmail.com
}

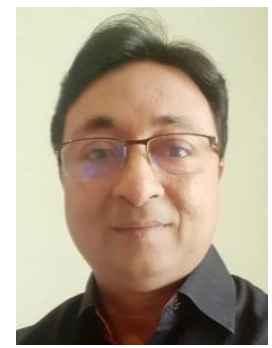

\section{Bhaskar Chakrabarti}

Public Policy and Management Group Indian Institute of Management Calcutta Kolkata, India

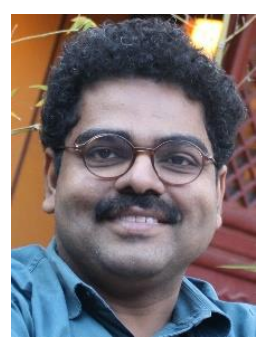

Email: bhaskar@iimcal.ac.in

\begin{abstract}
This paper is about the role of local democracy and governance to achieve the sustainable development goals (SDGs). Increased reliance on locally generated revenue, difficulties in managing networks of actors with diverse goals and objectives, imperfect flow of information, and trust deficit in stakeholders pose major challenges to achieving SDGs locally. By doing a systematic review of the recent literature on decentralisation with examples from different local governments, the paper outlines ways in which these challenges could be addressed. The paper also highlights the need for enhancing local leadership capabilities and demarcation of responsibilities among local politicians and bureaucrats, a point missed in the SDG agenda.
\end{abstract}

Keywords: SDG implementation, decentralisation, local democracy, governance, Agenda 2030

\section{Introduction}

This paper is about the role of local democracy and governance in implementing the sustainable development goals (SDGs). Each goal has a set of specific targets to be achieved by 2030. There has been a global consultation process around the SDGs particularly through national and regional 
consultations as well as the opportunity for organisations and individuals to contribute online. This paper seeks to consider the importance of local governments in implementing the SDGs and critically analyse the moulding of higher-level policy to local priorities (Amis 2013, Slack 2014, CLGF 2015). Recent studies show that policy response of a local government to global issues such as those highlighted in the SDG is often influenced by local political leanings, or at most, is driven by the actions of neighbouring as well as state/national governments when adopted at the local level (Hughes et al. 2018). From participatory governance to partnership with different stakeholders, from leadership response to fiscal decentralisation, we ask in this paper, where does the current academic literature on local governments situate localisation of global goals like SDGs and what is the relevance of such discussions for practice?

The paper is structured in four sections. Following the introduction, in section two, we focus on partnerships (SDG 17), economic growth and strong institutions (SDG 8 to 16), and on well-being, equality and affordability (SDG 1 to 7), in that order. Here, we discuss four issues with regard to adoption of these SDGs in local governance and democracy: a) intergovernmental relations, b) locally raised revenue, c) political and bureaucratic leadership, and d) local participation in decision-making processes. Section three discusses recent innovations in local governance, with a focus on SDG 9, and section four concludes by highlighting the key questions to guide the development of a Local Government Vision 2030.

Rapidly changing and more complex governance environments have resulted in problems with regard to limitations of local consultation and coordination across the range of stakeholders. This is further complicated by growing citizen demands and complex planning needs. The current literature on challenges in local governments could be summarised as the following:

a) institutional arrangements including intergovernmental relationships, both vertical and horizontal, as well as partnerships;

b) political economy of decentralisation, including the political will of the politicians, and their working relationship with the bureaucrats;

c) bureaucratic environment, including financial management;

d) local politics, including people's participation, accountability; and,

e) international developmental assistance (Smoke 2015).

We situate this paper within the broad challenges identified by Smoke (2015), and discuss them in the context of achievement of SDGs. We do not visit the context of international development assistance in this paper, as this would require a focus on several external factors. Rather, we analyse the first four challenges in detail in the context of SDG implementation. Inter-institutional harmony at the local level is often considered to be of the 'utmost importance' (Geldenhuys 2008). The existing literature on coordination for local governance throws considerable light on how to manage such networks, but 
relatively less attention has been paid to understanding the obstacles faced by networks (McGuire and Agranoff 2011). The political will of elected representatives at the local level and the contest of nested hierarchy within which it works, along with the mechanisms by which political disagreements are addressed by elected representatives and bureaucrats, and in turn, the effect of such disagreements on local policy decisions could prove extremely important in adopting the SDG goals (Reddy 2016). The current literature also identifies interweaving of political and fiscal decentralisation to be one of the most important challenges (Drew and Ryan 2016; Zhang et al. 2016; Smoke 2019) which is crucial for local democracy (Faguet and Pöschl 2015). Sometimes, the degree of decentralisation itself is a problem, where a supposedly decentralised system, as Eng (2016) argues in the context of Cambodia, is forced to depend on the national government for decisions on spending of local resources. One of the dangers of decentralisation is that it may create 'pseudo-participation' and actually empower local elites (Chakrabarti 2016). The truth of claims of participatory development is repeatedly challenged in the academic literature which suggests that it is necessary to analyse the role of 'local elites' or 'big men' in access to resources and decision-making processes (Kothari 2001).

The methodology used in this paper uses a systematic review of the recent literature on decentralisation with a focus on the first four key challenges that need be addressed in order to facilitate local government's role in the effective delivery of the SDGs. While we make an iterative effort to address issues from across different countries by bringing concrete examples that give evidence of the arguments posed, it must be noted that local government covers a very wide range of situations and institutions ranging from primary, secondary and mega-cities, to rural areas, small states and large federal countries. We attempt to capture this diversity in the paper.

\section{Challenges faced by local governments in local democracy and governance}

The current literature on local governance and democracy identifies four major challenges. These include: a) coordination and intergovernmental relations, b) fiscal decentralisation, c) political leadership and bureaucratic enforcement; and d) deliberative democracy and participation. In this section, we attempt to contextualise the SDG goals within these challenges, and discuss the way they might address the problems of local governance in general.

\section{Organised local governance: SDG 17 on partnerships for the goals}

Implementation of the SDGs is likely to require strong and effective partnerships between local, provincial and national governments, as well as other actors including civil society and the private sector. Evidence shows that coordinating actions of multiple agencies involved in policy implementation is a common challenge faced by many local governments. Different measures such as reducing the number of agencies, clarifying roles and responsibilities, increasing managerial capabilities (Dollery et al. 2008), improving intergovernmental relations (Geldenhuys 2008) and re- 
centralisation in the form of shared services (Dollery et al. 2009) have been attempted to address the issue of coordination. However, most of these attempts show mixed results.

While managerial reforms such as corporatisation and commercialisation have had some positive impact on improved efficiency, they usually come at the cost of responsiveness and accountability. Similarly, realignment of functions results in simplification of processes but, in some cases, it has contributed to increasing the level of complication (Dollery et al. 2008). Again, structural reforms such as a reduction in the number of hierarchical levels and merger of smaller bodies to create larger multipurpose bodies have resulted in the emergence of different models of public-public partnerships (Tomkinson 2007). The creation of multi-purpose bodies has mostly led to better coordination; however, it is fraught with the danger of creating public organisations that are too large to be efficient (Dollery et al. 2008). Thus, the problem of coordination still remains as one of the major challenges to be addressed (IDEA/CLGF, 2014). Three issues seem to be most relevant in achieving SDG 17 on partnerships: trust and cooperation, access to information, and overcoming institutional barriers.

\section{Addressing issues of trust and cooperation}

Recent studies on local governance emphasise the relationship between trust and welfare state at the grassroots with a focus on efficiency (Camussi et al. 2018). Familiarity and mutual dependency in governments facilitate trust (Ysa et al. 2014) and create a basis for continued cooperation. Pre-existing cooperation is known to reduce transaction costs of joint action through development of trust enhancing norms and by providing information on the anticipated behaviour of different actors involved (Kwon and Feiock 2010). Service level agreements also enhance trust if they take care of the core interests of all concerned actors. However, this is time-consuming as it can only be achieved through a process of intense bargaining where each actor possesses the power to veto and walk out of the agreement (de Bruijn and Heuvelhof, 2008). With the increased complexity of actors in local governance, the local government officials and elected representatives are present along with officials from the "line departments', and the process could also involve civil society organisations, and private partners (Chakrabarti et al. 2011). In some cases, there could be issues of cooperation in a nested hierarchy, for example where the Member of Parliament and/or traditional leaders might try to influence the local service delivery.

Empirical studies on rural local government cooperation indicate that the existence of a working relationship, either at interpersonal or at intergovernmental level, is essential for successful collaboration. Any past history of confrontation and mistrust is also likely to act as a barrier to future cooperation (Ruggeri et al. 2013). While membership of regional councils does not necessarily lead to greater cooperation, such forums provide the platform for discussing common problems and building relationships towards potential collaborations. 


\section{Challenges in access to information}

Ensuring timely and accurate information about actors possessing resources for achieving a strong partnership (Agranoff 2014) as well as about actors who can obstruct goal accomplishment (de Bruijn and Heuvelhof 2008) is the first step in forging a successful collaborative network. Limited or imperfect information about collaborative partners increases the transaction cost of collaboration (Kwon and Feiock 2010). Existence of a cyclical relationship between trust, information exchange and willingness to relinquish control is well known (Poocharoen and Ting 2015), and often lead to underlying problems remaining unresolved and can impact future coordination. Coordination is known to involve a) information sharing, b) resource sharing, and c) joint action. Out of these, information sharing is possibly the easiest and most critical because it is a precondition for the other two (Lecy et al. 2014). Availability of information is also necessary for synchronising actions of different agencies involved in joint action, particularly in an uncertain environment. Adoption of pacing techniques such as defining milestones and specifying events or timings when certain action becomes due can reduce uncertainty and facilitate coordination (Jones and Lichtenstein 2008). Studies we have undertaken on rural local government in India (Chakrabarti 2013) show that availability of key information and coordination on a) amount spent and b) timing of fund allotment by higher tiers of government enables the lower tiers to plan activities in advance. Problems with access to information for monitoring SDG progress at the subnational level could also result in non-achievement of the goals, as evident in Mumbai slums where both sanitation and housing targets fell short considerably (Lucci and Lynch 2016).

\section{Removal of institutional barriers}

The cost inherent in enforcement of conventional contracts such as service level agreements requires creation of institutions which can manage these effectively. However, they can also be the biggest challenge to collaborative functioning due to difficulties which result in aligning existing rules, procedures and performance metrics with those required for successful collaboration (Cristofoli et al. 2015). The importance of institutional barriers to partnership leads to the finding that it is easier to achieve collaboration while establishing a new service vis-à-vis achieving meaningful collaboration in an existing service (O'Leary and Vij 2012). While this could be achieved through a convergence around local development as an outcome of reform, Schoburgh's work on Trinidad and Tobago and Jamaica reveals that there might also be a divergence in the approach to achieving local development. In such cases, she argues in favour of a cohesive model in addressing development (Schoburgh 2012).

\section{SDG 8 and 16 on economic growth, justice and strong institutions}

Evidence shows that decentralisation of functions has often not been accompanied with commensurate decentralisation of financial power (Stone 2015). Although greater decentralisation of taxation leads to increasing electoral accountability of local politicians (Awortwi 2010), inadequate fiscal 
decentralisation continues to be one of the most common barriers to local government autonomy (Kroukamp and Leus 2008), and effective service delivery (Smoke 2017).

Many small or rural local governments for instance, have very little access to own-source revenue and rely on limited transfers of funds from higher tiers of government. Similarly, a big share of funds available to municipalities is still in the form of central grants, not only in developing but also in most developed countries. In localising SDG goals in Austria, England and Italy, Barbera et al. (2017), argue that local governments might need to go beyond country-based characterisations of public organisations to focus on a more decentralised context. Tanzania is showing a new way, where the district is the main unit in the process of a 'development by devolution' system. Here, they prepare their budgets that are financed by both the local and the central governments (Mwamunyange 2013). The growing realisation of the risks associated with central fund transfers has led to the emergence of second generation fiscal federalism wherein local governments are given greater autonomy to raise funds from own-source revenue to finance their day to day operations (Weingast 2009). Recent studies of urban local governments show that more autonomous governments spend less per capita on core services and support the argument that increasing fiscal decentralisation leads to more effective electoral accountability of local politicians (Boetti et al. 2012).

Greater reliance on locally raised revenue also has a strong relationship with the mutual cooperation between different local governments as the possibility of adopting shared services increases (UNDESA 2008; Silvestre et al. 2019). This is corroborated by studies on local government institutions where financial incentive is found to be the most important reason for adopting shared services (Niehaves and Krause 2010, Kortt et al. 2016). Studies exploring the relationship between fiscal health and cooperation show that cities with lower per capita tax revenue are more likely to cooperate (Leroux and Carr 2007). Even with funds allocated from higher tiers, the effectiveness of disbursement and utilisation is often influenced by the relationship between the executives of the local governments and the elected representatives (Appiah-Agyekum et al. 2013). However, not all fiscal decentralisation leads to lower expenditure at the grassroots. Zhang et al. (2016), in their analysis of the province-over-country scheme of China, highlight that local discretion could be associated with fiscal decentralisation, but it cannot allocate more resources on high-priority areas like education, which continues to be an increased outlay. Further, Smoke (2019) argues that while enabling more subnational borrowing can often be desirable, it does require other reform policies to improve the fiscal capacity and creditworthiness of local governments.

\section{Leadership in achieving the SDGs}

While the current literature on the importance of local government leaders as key drivers of local democracy, good governance and development are considerable (Bendor and Meirowitz 2004; Peters 2007; Hambleton 2015), surprisingly, the SDG goals talk mainly about strong institutions, but do not 
address the issues of leaderships directly. Neither do the SDGs emphasis a stronger politicianbureaucracy interface, a theme that the academic literature has started having a re-look at, along with its renewed interest in street-level bureaucracy. In this section, we look at the issues of political leadership, politician-bureaucracy interface and the role of street-level bureaucracy in achieving the SDGs.

\section{Political leadership and meta-governance}

The support of the political leadership is known to be crucial to responsive, reflective and accountable local government and the possibility of successful cooperation is virtually non-existent without it (Walsh et al. 2008). Their democratic mandate is central to their position as strategists, conveners and brokers. The underlying dilemma confronting politicians is whether to give up some degree of authority to achieve regional coordination, especially in the face of popular opposition to the proposal from local constituents (Feiock 2009). The role of the political leadership assumes importance when a large number of diverse actors take decisions based on incentives and penalties depending on the nature of various actors and the situations concerned (Meuleman 2008; Larsson 2013). A traditional bureaucracy may not be best suited to managing a multi-actor network due to the increased need for negotiation and trust (Nyholm and Haveri 2009). The flexibility inherent in political decision-making processes makes political leadership better suited for accommodating and negotiating conflicting goals and objectives (Stoker 2006). The National Confederation of Municipalities of Brazil has started a process of multilevel governance by bringing together actors from different tiers; in 2015, the Government of Colombia has also started similar initiatives through multilevel dialogues (Global Taskforce and UN Habitat 2016). Ecuador has gone one step further by creating territorial working groups and linking them up at the national level (Global Taskforce and UN Habitat 2016). However, achieving metagovernance is not easy and requires defined capabilities and involves proper training for personnel (Sansom 2013). Such capacity building has not happened to the desired extent in many places (Rahman and Singh 2011). In Malawi, for example, long periods of not holding elections for local governments and the absence of councillors almost paralysed local governance, prior to its reestablishment in 2014 (Tambulasi 2011; CLGF 2018). In Kenya, local governance meta-governance structures have been found to be dysfunctional and largely driven by external agencies such as international donors (Beisheim et al. 2017). Increasing ownership of localisation might lead to some sort of metagovernance, although this needs to be associated with local capacity building (Beisheim et al. 2017).

\section{Politician-bureaucracy relationship}

The political executive and local government bureaucracy are two major actors in any policy network. However, depending on circumstances, they can develop either collaborative, adversarial or submissive relationships (Peters 2007). An adversarial relationship develops when the two compete for power and could result in non-achievement of SDGs. A collaborative relationship develops when their interests 
converge. Lack of capacity on the part of local politicians can lead to transfer of effective power to bureaucrats, which may or may not be beneficial with regard to SDG achievement. Prolonged rule by a single party often leads to politicisation of the bureaucracy. In certain cases, bureaucrats and politicians belonging to a particular department develop collaborative relationships among themselves, which can result in adversarial relationship with officials belonging to other departments (Peters 2007). A bureaucracy-politician relationship that is shrouded in mistrust and subject to power struggles can lead to complete breakdown of local government. Representative bureaucracy, where the bureaucracy reflects the composition of the citizenry, can make bureaucracy more responsive to people's needs and reduce conflict with the political leadership. Similarly, bureaucracy accountable to political leadership can lead to achieving the dual objective of efficiency and democratic accountability (Deleon 2007). With examples of two cases on the administrator's perception of the politicians, Hulst et al. (2015) argue that perception of the politicians by the bureaucracy also plays an important role for collaboration, of which educational qualification of the politicians could be a factor. In one case, where primary education was the highest education of local councillors, the administrators expressed low opinion about their capacities. In another municipality, administrators were generally satisfied with graduate degrees of the councillors and their related capacities (Hulst et al. 2015).

\section{The role of street-level bureaucracy}

Street-level bureaucracy, a very important stakeholder in the implementation of the SDGs, defines the individuals who carry out and enforce laws and public policies. Street-level bureaucracy is accompanied by the idea that these individuals vary the extents to which they enforce the rules and laws assigned to them (Weatherley and Lipsky 1977). The role of street-level bureaucrats in shaping policy outcomes lies in applying discretion in the face of the gap between policy guidelines and popular expectations (Winter 2012). Tummers and Bakers (2014) argue that the street-level bureaucrats develop a capacity to shape policy 'on the spot' through their interactions with citizens and utilisation of discretion. Public service delivery in local governance, then, is not simply the result of the laws, but the everyday decisions of the street-level bureaucrats through their interactions with the stakeholders.

There is a growing realisation about the importance of professional judgement by frontline staff. Reviewing research on the role of street-level bureaucrats in adult social care in England shows that proliferation of bureaucratic procedures for ensuring accountability of public funds, and existence of conflicting rules not only necessitates discretion by frontline staff, but it also shows such discretion is supported by tacit approval by higher managerial staff (Kathryn 2011). Evaluation studies on implementation of a community health fund show that the unwillingness of frontline staff to apply discretionary power has led to exclusion of marginalised sections of the population from benefiting from the scheme (Kamuzora and Gilson 2007). 
The growing proliferation of e-government has made application of discretionary power more difficult and there is a danger of decreasing responsiveness of policy implementation by restricting the scope of arriving at locally negotiated solutions to societal problems (De 2008). Despite such apprehensions, it is seen that procedural manuals of most information and communication technology (ICT) systems are so elaborate that it creates greater possibility of discretion with sufficient choice of 'what to follow' and 'what to ignore' (Shaw et al. 2009). In fact, recent work on implementation of a rural medical insurance scheme in India involving end-to-end computerisation shows that frontline bureaucrats continue to play a critical role by enabling marginalised actors to conform to the requirements of the rigid software system (Guha and Chakrabarti 2015).

The above discussion shows that street-level bureaucracy continues to play an important role in increasing responsiveness of any policy implementation, and more so for SDG related goals. In fact, emphasis on improving public service through co-production, argued by Needham (2007) over a decade ago is likely to see an enhanced role of street-level bureaucracy. However, this might require an insulation of street-level bureaucrats from political bias to prevent exclusion based on political affiliation and ensure bureaucratic accountability. Although the space available to street-level bureaucrats has shrunk considerably due to the advent of e-governance, their role has become all the more important due to their ability to impart human values to rigid software logic.

\section{Achieving SDGs 1-7 on well-being, equality and affordability through deliberative democracy}

In the context of well-being, equality and affordability, goals that are prescribed in SDG 1-7, three issues would be relevant: participation of people in the decision-making process, inclusiveness in service delivery, and addressing of local needs. All are well-discussed in the literature on decentralisation. In this section, we revisit some of the recent literature and examples and discuss the role that local governments might play with regard to these issues the process of adoption of SDGs.

\section{Participation and creation of effective channels of public feedback}

Participation in policymaking is important because absence of participation leads to a disconnection between people's needs and the service provided, non-sustainable policy outcomes and increases the risk of beneficiary groups remaining perennially dependent on external assistance. Interaction between diverse stakeholders is also likely to improve the quality and legitimacy of decisions (Saito 2008). However, participation not only involves contribution in terms of resources and labour but outcomes of participatory processes may reflect the views of the more powerful sections of citizens (Chambers 2005; Cabannes 2019). Participation in multi-actor local government networks is even more difficult because a large part of the decision-making process takes place through informal interactions (de Bruijn and Heuvelhof, 2008; Popering-Verkerk and Buuren 2016). Moreover, existence of veto power increases the possibility of such decisions ignoring the interests of the less powerful and marginalised actors. 
Growing involvement of a large number of private or civil society actors can lead to a greater proportion of decisions being taken outside the public view and control of public representatives. Thus, notwithstanding its importance, participation may be difficult to achieve in local government decisionmaking processes. This is in part reflected in ordinary citizens' decreasing interest in traditional political processes. Lack of public participation is not only an issue in developed countries but increasingly also pertains in developing countries.

The above discussion shows that mere decentralisation of political authority is not sufficient to elicit public participation. Proactive measures need to be taken to facilitate greater public participation in the decision-making process. State-sponsored forums may not be sufficient to elicit participation of marginalised actors because such forums represent existing structures of dominance (Chattopadhyay et al. 2010). Thus, increased communication among stakeholders where everyone can articulate their interests is more effective than town square meetings. Cabannes (2019) argues that monitoring the growing instances of participatory budgeting globally could be seen as an important aspect of monitoring participation at the local level for SDG Target 16.7 "To ensure responsive, inclusive, participatory and representative decision-making at all levels". Forums dedicated for participation of certain sections of society might also be useful. For example, while earlier forums in Fiji had a focus on national government and getting women into parliament, in 2013, the Fiji Women's Forum (FWF) identified local governance as one of its focus areas. This provided local women with the opportunity to discuss avenues for inclusion of women in decision-making processes at the level of local governance (CLGF 2012). Ghana, in a unique attempt in partnership with the Institute of Local Government Studies (ILGS) and the Local Governance Network has recently launched a project to maximise participation of non-state actors in local governance, especially traditional authorities (GhanaWeb 2014). Such conscious attempts might be needed elsewhere too. India started women's reservation in local government elections some years ago; now Zambia has chosen the same path (All Africa News 2014).

Since sharing information and consultation with stakeholders are critical to participation (Halachmi and Greiling 2013) so, use of ICT can provide an alternative platform for enhancing participation. In Manitoba, Canada, for instance, the provincial government is providing new tools for municipalities to facilitate consultation with citizens on amalgamation plans. Municipalities are provided with access to a website with information and resources along with an amalgamation guidebook that outlines all the existing tools to look after local interests (Manitoba 2013). In the UK, Welsh local authorities have brought in enhanced transparency by making council proceedings more accessible to the public through a process of web-consultation. The website also enables remote attendance of councillors at council meetings (Welsh Government 2014) enabling greater representation, especially from across rural authorities covering large areas. Local government in Scotland is also engaging citizens in online consultation through the Commission of Strengthening Local Democracy (COSLD Scotland 2014). On another note, local government authorities in New Zealand have decided to try out an e-voting platform 
for local elections during 2016 (Department of Internal Affairs 2014). Initially, this will be available on a trial basis for some local government units.

While the above examples show that e-governance has played a positive role in many local governments, learning how to use new technology can itself become a barrier (Jun et al. 2014). Through a study of US local government websites, Grimmelikhuijse and Feeney (2016) argue that technological capacity becomes an important determinant across all distinct drivers for open government, accessibility, transparency and participation. Moreover, a greater focus on service delivery and information dissemination has prevented e-government projects from acting as a platform for facilitating greater participation. Rapid penetration of internet-enabled mobile phones has led to the emergence of social networks which have the potential of emerging as an alternative platform for deliberation and participation (Mervyn et al. 2014). Experiments with Community Radio, now popular in Ghana and India, might also be important devices to promote local participation in the future (Shukla 2014; Patil 2014; Awowi 2010).

\section{Addressing partisan politics and exclusion}

Being institutions of grassroots democracy, local government institutions are inherently political in nature. While flexibility of the political decision-making process is necessary for dealing with diversity of interests and involvement of political officials is necessary for imparting democratic legitimacy to decisions of local governments, involvement of party politics can lead to tension due to the emergence of adversarial relationships (Bogason and Musso 2006). Adoption of SDGs might help the local governments to maintain a focus on delivery to the whole community once the election for seats is over. For example, recent work in India shows that the presence of an equal number of representatives belonging to ruling and opposition parties resulted in complete stalling of project implementation, as the political leadership became unable to finalise project locations (Abraham et al. 2013).

\section{Provision of services as per local needs}

The difficulty in responding to increasing diversity of a population is one of the major justifications for decentralisation (Saito 2008). Local governments being closer to the people are better placed in understanding and responding to their needs (Kroukamp and Leus 2008). Greater emphasis on efficiency has led to the dominance of technocrats, resulting in decisions that bear greater influence on professional interests (Nyholm and Haveri 2009). Thus, it has become necessary to connect ordinary citizens or community representatives with service providers. However, lack of adequate resources or organisational clout weakens the position of such citizens' representatives. This is possibly more pronounced in cases of tension between a 'new' system of governance and a 'traditional' system that might have existed (Hassall et al. 2011). There is also a real risk of targets which are globally set, nationally adopted and then planned and delivered locally, resulting in the local government becoming more of an agent of the central government rather than responsive to the needs of local people. Gooden, 
in her recent work (2017) elaborately discusses the adoption of an equity plan from the City of Portland, Oregon, which includes 21 primary measures of equity including kindergarten readiness, graduation rates, median household income, food security, foreclosure risk, uninsured adults, and perceived neighbourhood safety. While these are important measures of inclusion, an assessment needs to be made as to whether the local communities and the city government work together in achieving targets associated with such goals.

Realising the importance of enhancing the capacity of citizens and communities led to the adoption of the local government modernisation agenda in Britain in the early 2000s (Martin and Bovaird 2005). For achieving meaningful co-governance, it is necessary to support and develop community and citizen's organisations on a long-term basis (Somerville and Haines 2008). ICT can play a significant role in making service provision responsive to local needs and in altering the citizen-service provider relationship (Pina et al. 2010). The urge for providing services as per local needs has also led to implementation of customer relationship management (CRM) solutions by a growing number of local governments. Although early studies on CRM implementation by British local governments indicate that it is being used mainly for answering citizen's queries and grievance redressal mechanisms (King and Cotterill 2007), it has the potential to achieve much more. It has been used extensively by private sector firms for analysing customer needs and has the potential for processing a large volume of data regarding requirements of different types of citizen. An example of how far such ICT development can go is Wiltshire Council who, in partnership with Microsoft, have enabled a fully interactive online access to their citizens for all council engagements (Microsoft 2018).

\section{Innovations in local governance: achieving SDG 9}

Municipalities, towns and rural local governments are constantly trying to innovate to improve service delivery, fiscal decentralisation, intergovernmental coordination, and to strengthen the relationships between politicians and their officials.

The city of Vancouver, Canada won the inaugural Guangzhou International Award for Urban Innovation for its Greenest City and housing affordability initiatives in 2012 (City of Vancouver 2012); Local Government New Zealand and the Institute of Directors are working towards a partnership to strengthen governance where mayors and fellow councillors will be incentivised (LGNZ 2013); or the creation of a collective Municipal Bond Agency in the UK which will cut the cost of borrowing to deliver new infrastructure (LGA 2014).

Melbourne municipality adopted a plan to make it a smoke-free city in 2016 (City of Melbourne 2015), following a high-profile participatory budgeting process of 2014 where the citizens, along with the municipality, decided how the city's $\$ 5$ million budget was to be allocated for the next ten years (Christensen and Grant 2016). Here, we see innovations in building trust at the local level by adopting 
democratic practices through fiscal decentralisation (availability of budget) as well as the availability of the authority for such discussions (Christensen and Grant 2016). Decentralisation, primarily political, itself has been used as an innovative strategy in bringing forth post-conflict stabilisation in Sierra Leone through a gradual process of elections and political representation (Edwards et al. 2015). We see innovations from Uganda under the Strengthening Decentralisation for Sustainability (SDS) programme for improving service delivery by local government through exploring new ideas (Natamba 2013). A recent review of arm's-length models used in local government in New Zealand has identified them as an alternative way to govern council-controlled organisations providing that there is a) clarity about the local government's purpose and strategic direction, b) clarity about roles, c) a proper human resource management approach in recruiting the right people, and d) transparent processes and effective relationships (Wellington City Council 2012; McKinlay 2013).

A number of innovations are also taking place with regard to participation of private partners. There is evidence that using market instruments such as contracts and incentives can help councils address complex issues such as healthcare and social welfare where activities and outcomes are not amenable to accurate outcome measurement (see Atkinson 2005). The involvement of private parties can reduce cost and improve efficiency but can also result in placing large parts of public policy outside the purview of council control because private agencies are not answerable to citizens. As we see in recent studies of partnerships in Malawi, issues of trust and cooperation become crucial (Soublière and Cloutier 2015), as discussed earlier in the section on political leadership and meta-governance.

\section{Conclusion: key issues for a Local Government Vision 2030}

In this section, we re-iterate the main issues highlighted in this paper and emphasise the key ideas with regard to organised local government, including coordination with private partners, the relationship between elected representatives and officials, local participation in decision-making and fiscal decentralisation in achieving SDGs. We also discuss the relevance of these for practice. All these, however, are interrelated.

From the current debates on decentralisation that are discussed in this paper, two key issues seem to play a crucial role in enabling coordination, and making sure that local government can play a full role in delivery of development targets and specifically the SDGs: (a) resource dependency and (b) harmony of interest. Local government is in a unique position of being able to draw on a network of partners from across the community to deliver development. It is impossible to see how the SDGs could be implemented without recognition of local government's role. As a community leader, one of the key challenges for local government seems to be that of key actors coming together and agreeing on a shared vision. There are likely to be differences of culture, structure, goals and objectives among organisations and individuals. Trust between the actors may not be present from the beginning. In such cases, it is important to be make clear that local governments have transparent and accountable procedures to 
create agreements, and are prepared to consider compliance for any partner not adhering to agreements/contracts, as evident in the work of Camussi et al. (2018). The current literature repeatedly argues that building the capacity of local leaders is essential and its importance should not be overlooked (Beisheim et al. 2017; Tummers and Bakers 2014). Strengthening political leadership at the same time as developing a strong administration, with clearly defined roles and functions, to implement decisions and policies are essential prerequisites (Walsh et al. 2008; Feiock 2009; Hambleton 2015).

There is definite value in formal and informal forums for regular interaction between different levels of government. In the emerging context of adoption of global goals, it is clear that successful development will require multilevel governance and forums can provide a valuable opportunity for coordination and cooperation. A process starting with 'collaboration in minor activities' leading to 'collaboration in larger projects' is more likely to succeed.

Greater reliance on own sources of revenue and devolution of taxation power as evident in the literature is a necessary condition for autonomy. Indeed examples discussed in this paper from Cambodia, China and Australia show that where councils raise more of their own revenue there is a greater incidence of public scrutiny and transparency. Lack of access to resources will be an impediment to local government's ability to deliver the SDGs. Similarly the politics of resource allocation can have the same effect. Local governments which rely on central or state government for the bulk of their funding, and generate little revenue at the local level must be accountable for their use of resources to the higher level of government rather than the local community in line with the commitment to 'local selfgovernment'. However localisation of the SDGs will also require greater political will to localise access to the necessary resources as repeatedly argued by Smoke $(2015,2017,2019)$.

Strengthening the capacity of local governments to work effectively with other local partners such as other local governments, non-governmental organisations (NGOs), civil society groups or private sector partners is likely to help to ensure that limited resources are used well. One clear advantage of working with NGOs and civil society groups is to increase transparency, so that instances of opportunistic behaviour are easily detected through public scrutiny. Despite the pressure on local governments to follow the lead of the private sector and develop outsourced service and partnership arrangements, the barriers in terms of culture, differences in priorities and lack of experience in outsourcing are formidable. Public private partnerships (PPPs) can enhance the local government's capacity to develop integrated solutions, facilitate creative and innovative approaches, reduce cost, reduce delivery time and also, in some cases, transfer certain risks to the private partner. However, the current literature shows that this may require the development of, or access to new skillsets such as legal capacity, contract management, long-term financial risk analysis etc.

There is some evidence of far-reaching social change in some countries as results of reforms implemented at the local level. This has resulted in the local inhabitants enthusiastically participating 
in the governance process, and taking part in decision-making. But increasingly the number of active participants is falling. The problem of low participation is essentially a crisis of governance in situations of high complexity and uncertainty. Citizens must feel that they want to participate and their voices will be heard, and it is incumbent on local government to ensure that its processes are as transparent and open to scrutiny as possible. Improved communication, possibly also through the use of ICT, can help to promote the participation of a wider cross-section of the population, especially young people.

Finally, there is a real risk of targets which are globally set (such as the SDGs), being nationally adopted and delivered locally, resulting in the local government becoming more of an agent of the central government rather than being responsive to the needs of local people (Hughes et al. 2018), and the authors of this papers agree with this view. Strengthening the capacity of citizens and community representatives on a long-term basis to articulate their needs and monitor local service delivery still remains a challenge, though innovations such as participatory budgeting provide some significant opportunities (Cabannes 2019). Modern communication technologies and social media platforms could play a major, even transformative role, in participatory decision-making.

Innovation leading to new ways of governing at the local level will strengthen local development across the world; however, good governance is not an end in itself, but a process. The outcomes depend on the way such governance structures are implemented. If there are active citizens who can engage with responsive local government, we will certainly be able to write a new chapter on a better way of governing at the local level as a means of achieving the SDGs and specifically the realisation of Goal 16: Promote peaceful and inclusive societies for sustainable development, provide access to justice for all and build accountable and inclusive institutions at all levels by 2030 .

\section{Declaration of conflicting interest}

The authors declared no potential conflicts of interest with respect to the research, authorship, and/or publication of this article.

\section{Funding}

An earlier version of this paper was presented as a background paper to the Commonwealth Local Government Conference in Gaborone, Botswana and the authors duly acknowledge the support of the CLGF authorities.

\section{References}

Abraham, B.P., Chakrabarti, B., Chattopadhyay, R. and Nath, S. (2013) Wage employment: Impact of MGNREGS in Bardhaman, West Bengal. Journal of Rural Development, 32 (1), 19-31.

Agranoff, R. (2014) Local governments in multilevel systems: Emergent public administration challenges. American Review of Public Administration, 44 (4S), 47S-62S. https://doi.org/10.1177/0275074013497629 
All Africa News. (2014) Zambia - government pledges commitment to gender. Available at: http://allafrica.com/stories/201404291602.html

Amis, P. (2013) Local government: How does it fit into the post 2015 MDG agenda? Commonwealth Journal of Local Governance, (13/14), 4-16. https://doi.org/10.5130/cjlg.v0i13/14.3720

Appiah-Agyekum, N.N., Boachie Danquah, N.Y. and Kojo Sakyi, E. (2013) Local government finance in Ghana: Disbursement. Commonwealth Journal of Local Governance (12), 90-109. https://doi.org/10.5130/cjlg.v12i0.3275

Atkinson, T. (2005) Atkinson review: Final report. Measurement of government output and productivity for the national accounts. UK: Palgrave MacMillan. Available at: www.ons.gov.uk/ons/guide-method/methodquality/specific/public-sector-methodology/articles/atkinson-review-final-report.pdf

Awortwi, N. (2010) The past, present and future of decentralisation in Africa. International Journal of Public Administration, 33 (12/13), 620-634. https://doi.org/10.1080/01900692.2010.514451

Awowi, J.E. (2010) Ghana community information centres: e-governance success or mirage. Journal of EGovernance, 33 (3), 157-167.

Barbera, C., Jones, M., Korac, S., Saliterer, I. and Steccolini, I. (2017) Governmental financial resitance under austerity on Austria, England and Italy: How do local governments cope with financial shocks? Public Administration, 95, 670-697. https://doi.org/10.1111/padm.12350

Beisheim, M., Ellersiek, A., Goltermann, L. and Kiamba, P. (2017) Meta-governance of partnerships for sustainable development: Actors' perspectives from Kenya. Public Administration and Development, 38 (3), 105-119. DOI: 10.1002/pad.1810

Bendor, J. and Meirowitz, A. (2004) Spatial models of delegation. American Political Science Review, 98, 293309. https://doi.org/10.1017/s0003055404001157

Boetti, L., Piacenza, M. and Turati, G. (2012) Decentralisation and local governments' performance: How does fiscal autonomy affect spending efficiency? Public Finance Analysis, 68 (3), 269-302. https://doi.org/10.1628/001522112x653840

Bogason, P. and Musso, J.A. (2006) The democratic prospects of network governance. American Review of Public Administration, 36 (1), 3-18. https://doi.org/10.1177/0275074005282581

Cabannes, Y. (2019) The contribution of participatory budgeting to the achievement of the Sustainable Development Goals: Lessons for policy in Commonwealth countries. Commonwealth Journal of Local Governance, (21). Available at: https://epress.lib.uts.edu.au/journals/index.php/cjlg/issue/view/459

Camussi, S., Mancini, A.L. and Tommasino, P. (2018) Does trust influence social expenditures? Evidence from local governments. Kyklos, 71 (1), 59-85. https://doi.org/10.1111/kykl.12162

Chakrabarti, B. (2013) Decentralisation and the politics of water allocation in West Bengal. Journal of South Asian Development, 8 (1), 1-26. https://doi.org/10.1177/0973174113476993

Chakrabarti, B. (2016) Participation at the crossroads: Decentralisation and water politics in West Bengal. New Delhi: Orient Blackswan.

Chakrabarti, B., Chattopadhyay, R. and Nath, S. (2011) Local governments in rural West Bengal, India and their coordination with line departments. Commonwealth Journal of Local Governance, (8/9), 33-51. Available at https://epress.lib.uts.edu.au/journals/index.php/cjlg/issue/view/191

Chambers, R. (2005) Ideas for development. London: Earthscan. https://doi.org/10.4324/9781849771665

Chattopadhyay, R., Chakrabarti, B. and Nath, S. (2010) Village forums or development councils: People's participation in decision-making in rural West Bengal, India. Commonwealth Journal of Local Governance, (5), 66-85. Available at: https://epress.lib.uts.edu.au/journals/index.php/cjlg/issue/view/116

Christensen, H.E. and Grant, B. (2016) Participatory budgeting in Australian local government: An initial assessment and critical issues. Australian Journal of Public Administration, 75 (4), 457-475. https://doi.org/10.1111/1467-8500.12219

City of Melbourne. (2015) Smoking tobacco. Available at: www.melbourne.vic.gov.au/communityservices/health/pages/smokingtobacco.aspx

City of Vancouver. (2012) Vancouver wins international award for urban innovation Available at: https://604now.com/vancouver-wins-international-award-for-urban-innovation 
CLGF (2012) Fiji women's forum ends with stronger call for women's participation in local governance. Available at: www.clgf.org.uk/whats-new/news/fiji-womens-forum-ends-with-stronger-call-for-womensparticipation-in-local-governance

CLGF (2015) Local government 2030: achieving the vision - background paper. Available at: www.clgf.org.uk/default/assets/File/Publications/reports/Local_Govt_2030_Achieving_the_Vision_Conf erence_background_paperCLGF2015.pdf

CLGF (2018) The local government system in Malawi. Commonwealth Local Government Handbook 2017-19. London: Commonwealth Local Government Forum. Available at: www.clgf.org.uk/country-profiles

COSLD Scotland. (2014) Commission on Strengthening Local Democracy. Available at: https://scottishruralparliament.org.uk/resources/cosld/

Cristofoli, D., Maccio, L. and Pedrazzi, L. (2015) Structures, mechanisms and managers in successful networks. Public Management Review, 15 (4), 489-516. https://doi.org/10.1080/14719037.2013.798025

de Bruijn, H. and Heuvelhof, E.t. (2008) Management in networks. London, NY: Routledge.

De, R. (2008) Control, de-politization and the estate. In: Wimmer, M.A., Scholl, H.J. and Ferro, E. (eds.) EGOV 2008, (pp. 61-72). Turin: Springer. https://doi.org/10.1007/978-3-540-85204-9_6

Deleon, L. (2007) Public management, democracy and politics. In: Ferlie, E., Lynn, L.E. and Pollitt, C. (eds.) The Oxford handbook of public management, (pp. 103-130). Oxford University Press. https://doi.org/10.1093/oxfordhb/9780199226443.003.0006

Department of Internal Affairs. (2014) Online voting. New Zealand Government. Available at: www.dia.govt.nz/online-voting

Dollery, B., Garcea, J. and LeSage, E.C. (2008) Local government reforms. Cheltenham, UK: Edward Elgar.

Dollery, B., Akimov, A. and Byrnes, J. (2009) Shared services in Australian local government: Rationale, alternative models and empirical evidence. Australian Journal of Public Administration, 68 (2), 208-219. https://doi.org/10.1111/j.1467-8500.2009.00635.x

Drew, J. and Ryan, R. (2016) Giving local governments the reboot: Improving the financial sustainability of local governments. NSW \& Melbourne: The McKell Institute.

Edwards, B., Yilmaz, S. and Boex, J. (2015) Decentralisation as a post-conflict strategy: Local government discretion and accountability in Sierra Leone. Public Administration and Development, 35, 46-60. https://doi.org/10.1002/pad.1707

Eng, N. (2016) Decentralisation in Cambodia: New wine in old bottles. Public Administration and Development, 36 (4), 250-262. https://doi.org/10.1002/pad.1765

Faguet, J-P and Pöschl, C. (2015) Is decentralization good for development? Perspectives from academics and policy makers. Oxford, England: Oxford University Press. Available at: http://eprints.lse.ac.uk/63178/1/Faguet_is\%20decentralization\%20good.pdf

Feiock, R.C. (2009) Metropolitan governance and institutional collective action. Urban Affairs Review, 44 (3), 356-377. https://doi.org/10.1177/1078087408324000

Geldenhuys, A.J. (2008) The crux of intergovernmental relations. In: De Vries, M.S., Reddy, P.S. and Haque, M.S. (eds.) Improving local government, (pp. 88-106). Palgrave Macmillan. https://doi.org/10.1057/9780230287310_6

GhanaWeb. (2014) Local governance civil society groups get boost. Available at: www.ghanaweb.com/GhanaHomePage/NewsArchive/artikel.php?ID=299307

Global Taskforce \& UN Habitat (2016) Roadmap for localising the SDGs. Barcelona: UCLG. Available at: www.uclg.org/sites/default/files/roadmap_for_localizing_the_sdgs_0.pdf

Gooden, S.T. (2017) Social equity and evidence: Insights from local government. Public Administration Review, 77 (6), 822-828. https://doi.org/10.1111/puar.12851

Grimmelikhuijse, S.G. and Feeney, M.K. (2017) Developing and testing an integrative framework for open government adoption in local governments. Public Administration Review, 77 (4), 579-590. https://doi.org/10.1111/puar.12689

Guha, J. and Chakrabarti, B. (2015) RSBY implementation in West Bengal: A case study. Man in India, 95 (3). 
Guha, J. and Chakrabarti, B. (forthcoming) Co-ordination failure in policy networks.

Halachmi, A. and Greiling, D. (2013) Transperancy, e-government and accountability. Public Performance \& Management Review, 36 (4), 572-584. https://doi.org/10.2753/pmr1530-9576360404

Hambleton, R. (2015) Leading the inclusive city. Place-based innovation for a bounded planet. Bristol: Policy Press.

Hassall, G., Kaitani, M., Mae, P., Feue, T. and Wainikesa, L. (2011) Comparative study on local government and traditional governance systems interaction in Pacific Island countries. Governance Programme, University of the South Pacific.

Hughes, S., Runfola, D.M. and Cormier, B. (2018) Issue proximity and policy response to local governments. Review of Policy Research, 35 (2), 192-209. https://doi.org/10.1111/ropr.12285

Hulst, R., Mafuru, W. and Mpenzi, D. (2015) Fifteen years after decentralisation by devolution: Politicaladministrative relations in Tanzanian local government. Public Administration and Development, 35, 360-371. https://doi.org/10.1002/pad.1743

IDEA/CLGF. (2014) Local democracy today and tomorrow: Learning from good practice. Available at: http://www.clgf.org.uk/default/assets/File/Publications/reports/Local_Democracy_today_and_tomorrowlearning_from_good_practice-IDEA-CLGF-CityInsight2014.pdf

Jones, C. and Lichtenstein, B.B. (2008) Temporary inter-organizational projects. In: Cropper, S., Ebers, M., Huxham, C. and Ring, P.S. (eds.) The Oxford handbook of inter-organizational relations, (pp. 231-255). Oxford: Oxford University Press. https://doi.org/10.1093/oxfordhb/9780199282944.003.0009

Jun, K.-N., Wang, F. and Wang, D. (2014) E-government use and perceived government transperancy and service capacity. Public Performance \& Management Review, 38 (1), 125-151. https://doi.org/10.2753/pmr1530-9576380106

Kamuzora, P. and Gilson, L. (2007) Factors influencing implementation of the Community Health Fund in Tanzania. Health Policy and Planning, 22, 95-102. https://doi.org/10.1093/heapol/czm001

Kathryn, E. (2011) 'Street-level bureaucracy' revisited: The changing face of frontline discretion in adult social care in England. Social Policy \& Administration, 45 (3), 221-244. https://doi.org/10.1111/j.14679515.2011.00766.x

King, S. and Cotterill, S. (2007) Transformational government? The role of information technology in delivering citizen-centric local public services. Local Government Studies, 33 (3), 333-354. https://doi.org/10.1080/03003930701289430

Kortt, M.A. Dollery, B. and Drew, J. (2016) Municipal mergers in New Zealand: An empirical analysis of the proposed amalgamation of Hawke's Bay councils. Local Government Studies, 42 (2), 228-247, DOI: 10.1080/03003930.2015.1007133

Kothari, U. (2001) Power, knowledge and social control in participatory development. In: Cooke, B. and Kothari, U. (eds.) Participation: The new tyranny. London: Zed Books.

Kroukamp, H. and Leus, L. (2008) Improving local management. In: De Vries, M.S., Reddy, P. and Haque, M. (eds.) Improving local government: Outcomes of comparative research, (pp. 107-131). New York: Palgrave. https://doi.org/10.1057/9780230287310_7

Kwon, S.-W. and Feiock, R.C. (2010) Overcoming the barriers to cooperation: Intergovernmental service agreements. Public Administration Review, 70 (6), 876-884. https://doi.org/10.1111/j.15406210.2010.02219.x

Larsson, O.L. (2013) Sovereign power beyond the state: A critical reappraisal of governance by networks. Critical Policy Studies, 7 (2), 99-114. https://doi.org/10.1080/19460171.2013.784624

Lecy, J.D., Mergel, I.A. and Schmitz, H.P. (2014) Networks in public administration. Public Administration Review, 16 (5), 643-665. https://doi.org/10.1080/14719037.2012.743577

Leroux, K. and Carr, J.B. (2007) Explaining local government cooperation on public works: Evidence from Michigan. Public Works Management \& Policy, 12 (1), 344-358. https://doi.org/10.1177/1087724x07302586

LGA. (2014) Municipal bonds in UK. Available at: www.ukmba.org/ukmba-pfm 
LGNZ (2013) Strengthening governance within the local government sector. Wellington: Local Government New Zealand.

Lucci, P. and Lynch, A. (2016) The SDGs at city level: Mumbai's expereince. Working Paper No. 32. London: Overseas Development Institute.

Manitoba. (2013) New tools to support municipal amalgamations. Available at: www.mysteinbach.ca/newsblog/19170.html

Martin, S. and Bovaird, T. (2005) Meta-evaluation of the local government modernisation agenda: Progress report on service improvement in local government. Office of the Deputy Prime Minister. Available at: www.bipsolutions.com/docstore/pdf/9882.pdf

McGuire, M. and Agranoff, R. (2011) The limitations of public management networks. Public Administration, 89 (2), 265-284. https://doi.org/10.1111/j.1467-9299.2011.01917.x

McKinley, P. (2013) The role of local authority-owned companies: Lessons from the New Zealand experience. In: Sansom, G. \& McKinlay, P. New century local government: Commonwealth perspectives. London: Commonwealth Secretariat.

Mervyn, K., Simon, A. and Allen, D.K. (2014) Digital inclusion and social inclusion. Information, Communication \& Society, 17 (9), 1086-1104. https://doi.org/10.1080/1369118x.2013.877952

Meuleman, L. (2008) Public management and the metagovernance of hierarchies, networks and markets. Heidelberg: Physica-Verlag. https://doi.org/10.1007/978-3-7908-2054-6

Microsoft. (2018) Wiltshire Council become one of the most cutting-edge councils in the country. Available at: https://customers.microsoft.com/en-gb/story/wiltshire-council-improves-services-dynamics-365

Mwamunyange, J. (2013) Tanzania devolves budget to districts. The East African. Available at: http://www.theeastafrican.co.ke/news/Tanzania-devolves-budget-to-districts-/-/2558/1898898/-/m79bf6//index.html

Natamba, P. (2013) Local government innovation in Uganda. All Africa. Available at: http://allafrica.com/stories/201302051454.html

Needham, C. (2007) Realising the potential of co-production: Negotiating improvements in public services. Social Policy \& Society, 7 (2), 221-231. https://doi.org/10.1017/s1474746407004174

Niehaves, B. and Krause, A. (2010) Shared service strategies in local government - a multiple case study exploration. Transforming Government: People, Process and Policy, 4 (3), 266-279. https://doi.org/10.1108/17506161011065235

Nyholm, I. and Haveri, A. (2009) Between government and governance: Local solutions for reconciling representative government and network governance. Local Government Studies, 35 (1), 109-124. https://doi.org/10.1080/03003930802574516

O'Leary, R. and Vij, N. (2012) Collaborative public management: Where have we been, and where are we going? The American Review of Public Administration, 42 (5), 507-522. https://doi.org/10.1177/0275074012445780

Patil, D.A. (2014) Exploring the subaltern voices: A study of community radio reporters in rural India. Qualitative Report, 19 (33), 19-33.

Peters, B.G. (2007) Politicians and bureaucrats in the politics of poilicy-making. In: Bevir, M. (ed.) Public governance, (Vol. 3, pp. 37-61). London, Thousand Oaks, New Delhi: Sage.

Pina, V., Torres, L. and Royo, S. (2010) Is e-government leading to more accountable and transparent local governments. Financial Accountability \& Management, 26 (1), 3-20. https://doi.org/10.1111/j.14680408.2009.00488.x

Poocharoen, O.-o. and Ting, B. (2015) Collaboration, co-production, networks. Public Management Review, 17 (4), 587-614. https://doi.org/10.1080/14719037.2013.866479

Popering-Verkerk, J.v. and Buuren, A.v. (2016) Decision-making patterns in multilevel governance: The contribution of informal and procedural interactions to significant multilevel decisions. Public Management Review, 18 (7), 951-971. https://doi.org/10.1080/14719037.2015.1028974 
Rahman, M. H. and Singh, S. (2011) Towards strong local governance: Current reform scenario in Fiji. International Journal of Public Administration, 34, 674-681. https://doi.org/10.1080/01900692.2011.587993

Reddy, P.S. (2016) Localising the sustainable development goals (SDGs): The role of local governments in context. African Journal of Public Affairs, 9 (2), 1-15.

Ruggeri, A., Gizelis, T.-I. and Dorussen, H. (2013) Managing mistrust: An analysis of the UN peacekeeping. Journal of Conflict Resolution, 57 (3), 387-409. https://doi.org/10.1177/0022002712448906

Saito, F. (2008) Decentralisation and local governance: Introduction and overview. In: Saito, F. (ed.) Foundations for local governance: Decentralisation in comparative perspective, (pp.1-24). Heidelberg: Physica-Verlag. https://doi.org/10.1007/978-3-7908-2006-5_1

Sansom, G. (2013) The evolving role of Mayors: An Australian perspective. In: Sanson, G. and McKinlay, P. New century local government, (pp. 212-239). London: Commonwealth Secretariat. https://doi.org/10.14217/9781848591493-14-en

Schoburgh, E.D. (2012) Local government and local development: Bridging the gap through critical discourse. Commonwealth Journal of Local Governance, (10), 5-31. https://doi.org/10.5130/cjlg.v0i10.2686

Shaw, I., Morris, K. and Edwards, A. (2009) Technology, social services and organizational innovation or how great expectations in London and Cardiff are dashed in Lowestoft and Cymtyrch. Journal of Social Work Practice, 23 (4), 383-400. https://doi.org/10.1080/02650530903374937

Shukla, M. (2014) Democratising information in India: Role of community radios as a development intervention. Vision, 18 (4), 349-352. https://doi.org/10.1177/0972262914551662

Silvestre, H.C. Marques, R.C., Dollery, B. and Moraes Correia, A. (2019) Is cooperation cost reducing? An analysis of public-public partnerships and inter-municipal cooperation in Brazilian local government. Local Government Studies, DOI: 10.1080/03003930.2019.1615462

Slack, L. (2014) The post-2015 Global Agenda - a role for local governance. Commonwealth Journal of Local Governance (15), 173-177. https://doi.org/10.5130/cjlg.v0i0.4069

Smoke, P. (2015) Rethinking decentralisation: Assessing challenges to a popular public sector reform. Public Administration and Development, 35, 97-112. https://doi.org/10.1002/pad.1703

Smoke, P. (2017) Fiscal decentralisation frameworks for Agenda 2030: Understanding key issues and crafting strategic reforms. Commonwealth Journal of Local Governance (20), 3-23. https://doi.org/10.5130/cjlg.v0i20.6024

Smoke, P. (2019) Improving subnational government development finance in emerging and developing economies: Toward a strategic approach. ADBI Working Papers, Asian Development Bank Institute. Available at: https://ideas.repec.org/p/ris/adbiwp/0921.html

Somerville, P. and Haines, N. (2008) Prospects of local co-governance. Local Government Studies, 34 (1), 61-79. https://doi.org/10.1080/03003930701770488

Soublière, J. and Cloutier, C. (2015) Explaining levels of local government involvement in service delivery: The dynamics of cross-sector partnerships in Malawi. Public Administration and Development, 35, 192-205. https://doi.org/10.1002/pad.1715

Stoker, G. (2006) Public value management: A new narrative for networked governance? American Review of Public Administration, 36, 41-57. https://doi.org/10.1177/0275074005282583

Stone, S. (2015) The effect of fiscal decentralisation on the financial condition of municipal government. International Journal of Public Administration, 38 (6), 453-460. https://doi.org/10.1080/01900692.2014.949740

Tambulasi, R. I. (2011) Local government without governance. Public Policy \& Administration, 26 (3), $333-352$. https://doi.org/10.1177/0952076710374915

Tomkinson, R. (2007) Shared service in local government. Burlington: Grower.

Tummers, L. and Bakers, V. (2014) Policy implementation, street level bureaucracy and the importance of discretion. Public Management Review, 16 (4). https://doi.org/10.1080/14719037.2013.841978

UNDESA. (2008) United Nations e-government survey 2008. From e-government to connected government. New York: UN Department of Economic and Social Affairs. 
Walsh, P., McGregor-Lowndes, M. and Newton, C.J. (2008) Shared services: Lessons from the public and private sectors for the non-profit sector. The Australian Journal of Public Administration, 67 (2), 200 212. https://doi.org/10.1111/j.1467-8500.2008.00582.x

Weatherley, R. and Lipsky, M. (1977) Street-level bureaucrats and institutional innovation: Implementing special-education reform. Harvard Educational Review, 47 (2), 171-197. https://doi.org/10.17763/haer.47.2.v870r1v16786270x

Weingast, B.R. (2009) Second generation fiscal federalism: The implications of fiscal incentives. Journal of Urban Economics, 65 (3), 279-293. https://doi.org/10.1016/j.jue.2008.12.005

Wellington City Council. (2012) An urban development agency for Wellington City. Available at https://wellington.govt.nz/ /media/have-your-say/public-input/files/consultations/2016/03-annualplan/uda-proposal.pdf

Welsh Government. (2014) Consultations. Available at: http://gov.wales/consultations/?lang=en

Winter, S.C. (2012) Implementation perspectives: Status and reconsideration. In: Peters, B.G. and Pierre, J. (eds.) Handbook of public administration, (pp. 265-278). London: Sage. https://doi.org/10.4135/9781446200506.n17

Ysa, T., Sierra, V. and Esteve, M. (2014) Determinants of network outcomes: The impact of management strategies. Public Administration, 92 (3), 636-655. https://doi.org/10.1111/padm.12076

Zhang, P., Zhu, C. and Hu, Y. (2016) Fiscal decentralisation, flat administrative structure, and local government size: Evidence and lessons from China. Public Adminsitration and Development, 36, 198-214. https://doi.org/10.1002/pad.1762 